\title{
Design and monitoring of energy-active facade module
}

\author{
Nikola Pokorny ${ }^{1}$, Tomas Matuska ${ }^{1}$, Vladimir Jirka ${ }^{1}$, and Borivoj Sourek ${ }^{1}$ \\ ${ }^{1}$ UCEEB, CTU in Prague, Bustehrad 273 43, Trinecka 1024, Czech Republic
}

\begin{abstract}
Testing of two facade modules under outdoor climatic conditions of Central Europe has been performed for more than two years. The paper analyses the results of long-term monitoring and shows potential benefits of prismatic glazing and photovoltaic-thermal (PVT) collectors integrated into one component. The prismatic glazing reflects beam radiation during summer period and transmits it during the winter period. During summer month solar irradiation transmitted through the prismatic glazing can be about $44 \%$ lower compared to conventional triple glazing. Glazed PVT collector generates heat and electricity simultaneously. PVT collector integrated in the façade module can achieve solar yield during summer $58 \mathrm{kWh} / \mathrm{m}^{2}$.month in heat and $6,3 \mathrm{kWh} / \mathrm{m}^{2}$.month in electricity.
\end{abstract}

\section{Introduction}

Nowadays the energy demand of the building sector is significant. To maximize the utilization of incident solar irradiation is crucial and important for buildings of future. Solar heat gains should be used in effective way. New solutions how to decrease consumption of nonrenewable energy are investigated and implemented. Solar radiation influences building consumption of energy. Due to this fact, it is desirable to increase solar heat gains during winter and decrease during summer. Possible approach to control the solar heat gains without any moving parts is the use of prismatic structures instead of mechanical solar control devices.

Besides the passive elements for reduction of energy consumption, facade components for active energy production are investigated as well. Photovoltaic-thermal collectors (PVT) are regarded as promising technology in area of energy supply for future buildings. PVT collectors started to be more relevant in the world in last years. Cumulated installed area of PVT collectors reached 1 mil. $\mathrm{m}^{2}$ by the end of 2018 [1]. Combination of solar thermal collector and photovoltaic panel can achieve up to $35 \%$ more heat and electricity compared to separate installation of conventional collectors in same area. In last decade the research in this field is still growing.

New prototype of energy-active façade module implementing prismatic glazings and glazed PVT collectors is presented in the paper. Solar components integrated into one facade module are described and analysed separately. Long-term monitoring of energy active façade module under climatic conditions of Central Europe has been carried out. Results from functionality evaluation in real environment are presented.

\section{Prototype of energy-active façade module}

New façade module was developed and fabricated with collaboration project with SKANSKA company. Small scale prototype of energy active façade for laboratory testing is shown in Fig. 1. Façade module combines several technologies. The module consists of three parts. At the top there is a triple low-e glazing with prismatic glass pane, in the middle is conventional triple low-e glazing, and at the bottom there is solar glazed PVT collector. The whole façade module size is $1,50 \mathrm{x}$ $2,18 \mathrm{~m}$. Glass raster size is $1,46 \times 1,00 \mathrm{~m}$. Gross area of the glazed PVT collector is $1,56 \mathrm{~m}^{2}$. The weight of the facade module is $120 \mathrm{~kg}$.

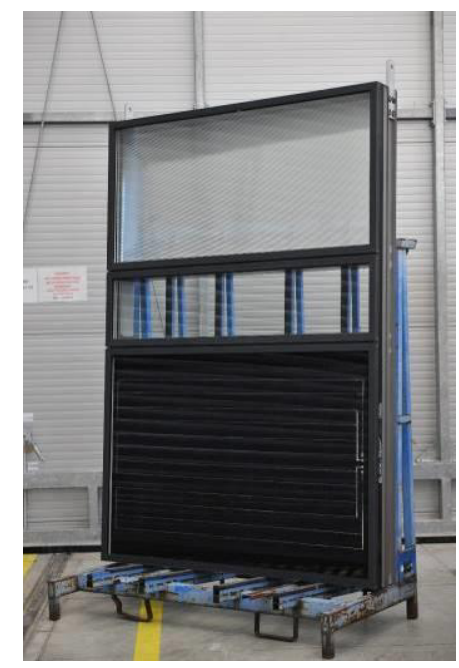

Fig. 1. Prototype of energy-active façade module

\footnotetext{
* Corresponding author: nikola.pokorny@,cvut.cz
} 


\subsection{Glazed PVT collector}

Combination of solar thermal collector and PV panel is very promising. Currently, research activities in PVT field are growing according to recent review [2]. The most studied alternative of PVT collector is with liquid as a heat transfer fluid. Different designs of liquid PVT collectors exist e.g. unglazed, glazed or concentrating PVT collectors. Unglazed PVT collectors can achieve higher electrical efficiency thanks to low operation temperatures and absence of any cover glazing. The most common application of unglazed PVT collector is the combination with heat pump or swimming pool solar heating. Glazed PVT collectors are convenient for medium temperature application. Glazed PVT collectors have stagnation temperature from $150{ }^{\circ} \mathrm{C}$ to $200{ }^{\circ} \mathrm{C}$ but maximum operation temperature of $\mathrm{PV}$ cells encapsulation material (ethylene-vinyl-acetate EVA) is around $85^{\circ} \mathrm{C}$ [3]. Lack of glazed PVT collectors available on the market is caused by the issue with the degradation of EVA encapsulation during high temperatures. One possible way how to prevent stagnation is overheating protection, for example by variable film insulation [4] or by ventilated internal space of collector during stagnation [5]. Another possible approach, which has been utilized for glazed PVT collector implemented in the facade module, is encapsulation material resistant to high stagnation temperatures applied instead of EVA [6].

Glazed PVT collector presented in this paper is based on sandwich structure (see Fig. 2). PV cells are encapsulated between a double glazing and the copper heat exchanger by means of polysiloxane gel. Polysiloxane gel as PV encapsulant offers a large range of operation temperatures (from -60 to $+250{ }^{\circ} \mathrm{C}$ ), high transparency for solar radiation and allows the compensation of thermal dilatation stresses thanks to low modulus of elasticity [7]. Main advantage of glazed PVT collectors is a large potential in the most common application in Europe which is preparation of domestic hot water. Glazed PVT collectors have comparable thermal efficiency with conventional thermal collectors. PVT collector is convenient especially for buildings with high heat demand and small available roof area. Two glazed PVT collector alternatives were constructed and integrated in investigated façade modules varying in optical properties of glass pane attached to PV absorber. For selective PVT collector glass pane with low emissivity coating (30\%) but with high transparency for solar radiation $(85 \%)$ has been used. Nonselective alternative of PVT collector has a low-iron solar glass pane with high emissivity ( $85 \%$ ) and high transparency for solar radiation $(91 \%)$. The front glazing in both designs is single solar glass pane with transparency $94 \%$ for both prototypes.

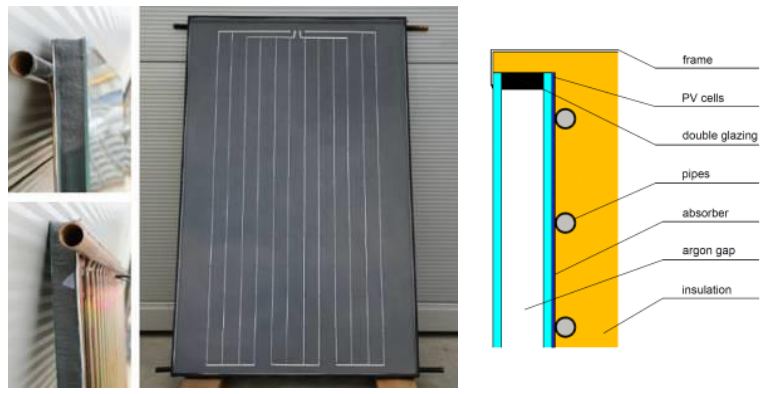

Fig. 2. Glazed PVT collector prepared for building envelope integration

The PV part of the collector has 60 cells at size $125 \mathrm{x}$ $125 \mathrm{~mm}$ in three parallel strings. Nominal efficiency of PV cell declared by manufacturer is $18.8 \%$ under standard test conditions. Area of PV part is about $60 \%$ of gross area. Gross area of PVT collector part in the façade element is $1.56 \mathrm{~m}^{2}$, aperture area is $1.4 \mathrm{~m}^{2}$. Thanks to integration of PVT collector into opaque part of facade module back side insulation is $140 \mathrm{~mm}$.

Nonselective PVT collector integrated into facade module has been tested under steady state conditions according to EN ISO 9806 at Solar laboratory (UCEEB $\mathrm{CTU}$ ) with use of indoor solar simulator. Required maximum uncertainty of measurement according to standard was respected. Characteristics of thermal efficiency have been evaluated in two modes (see Fig. 3), with and without electric load. In the hybrid mode, the PV part was connected to maximum power point (MPP) tracker with varying load. In open circuit mode, the PVT collector thermal performance was tested without connected electric load. Open circuit conditions correspond to thermal behaviour of conventional photothermal collector. Thermal and electric characteristics have been related to gross area of the PVT collector (see in Fig. 3). On the axis $x$ there is reduced temperature drop where $t_{\mathrm{m}}[\mathrm{K}]$ is mean fluid temperature, $t_{\mathrm{a}}[\mathrm{K}]$ is ambient temperature and $G\left[\mathrm{~W} / \mathrm{m}^{2}\right]$ is incident irradiance.

Open circuit test conditions were following: the global irradiance was kept at the average value $924 \mathrm{~W} / \mathrm{m}^{2}$ during the test. The collector tilt angle was set up to $45^{\circ}$. Ambient air temperature was fixed at $16.4{ }^{\circ} \mathrm{C}$. Collector zero loss thermal efficiency was evaluated 68 $\%$ (related to gross area). Stagnation temperature was determined $161{ }^{\circ} \mathrm{C}$.

Hybrid mode conditions were following: the global irradiance was kept at the average value $988 \mathrm{~W} / \mathrm{m}^{2}$ during the test. The collector tilt angle was set up to $45^{\circ}$. Ambient air temperature was fixed at $18.2{ }^{\circ} \mathrm{C}$. Collector zero loss thermal efficiency was evaluated $60 \%$ and the electrical efficiency $8.4 \%$ (both related to gross area). Stagnation temperature was determined $156^{\circ} \mathrm{C}$.

Similar thermal and electrical performance of glazed PVT collector was achieved also by other research groups $[4,8]$. Developed PVT collector has advantage in usage of high temperature resistant material as an encapsulant of PV cells, therefore PV part of the collector does not degrade during high temperatures. PV part can even operate during high temperatures for a long time. 


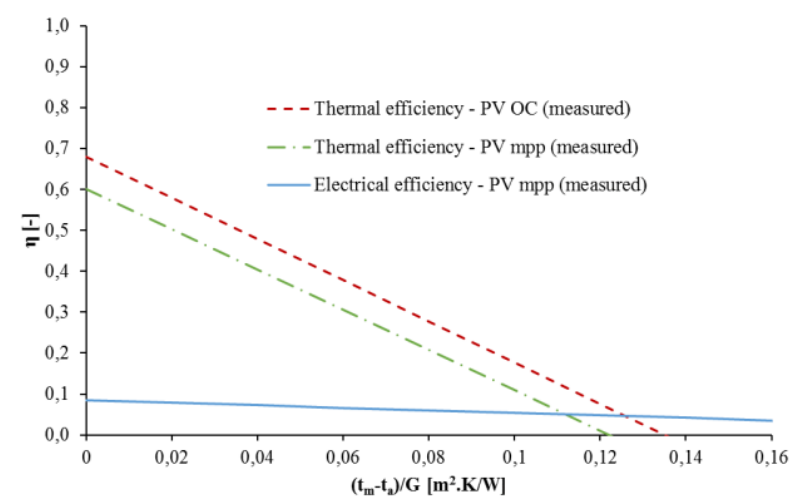

Fig. 3. Thermal and electrical characteristics for integrated PVT collector (related to gross area) from laboratory testing

\subsection{Prismatic structure for angle selective reflection}

Prism function for solar heat gains control is based on total internal reflection of sun rays at the interface between transparent material and air at given incidence angle. Undisputed advantage of the glass prismatic structures is cheap production method of continuous casting where the price for the prisms is similar to conventional float glass panes. Use of the glass prismatic components for angular selective reflection of solar radiation in buildings results in application of passive devices for solar control without any moving parts. For facade module two different types of prismatic glass structures have been implemented, originally developed for double glazing application in the greenhouses [9]. Geometry of the prismatic structure is adapted for climatic conditions of Central Europe but it is not difficult to modify for different climatic conditions. Geometry designs of glass prisms are shown in in Fig. 4. The alternative 1 uses the frontal asymmetrical prism with base angle $\gamma=13^{\circ}$ and angle $\beta=90^{\circ}$ (see Fig. 4, left). The alternative 2 uses the reverse symmetrical rectangular prism with base angle $\gamma=90^{\circ}$ (see Fig. 4, right). More information about the technology and experimental characterization of glass prismatic structures is published in experimental study by [10].

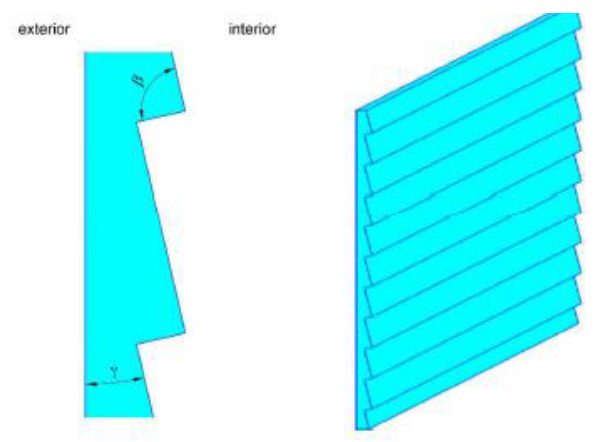

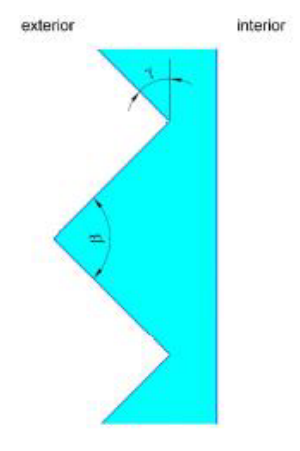

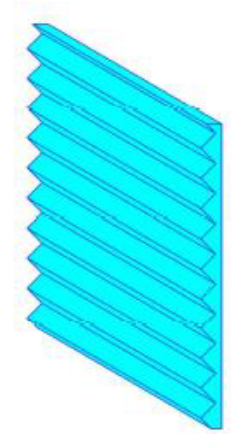

Fig. 4. Geometry of frontal asymmetrical prism (top) and reverse symmetrical (bottom) prism

Triple glazing for windows with integrated glass prisms were manufactured. The conventional triple glazing has been used for middle part of facade module for comparison. Fig. 5 shows the triple glazing designs. Each triple glazing used in facade contains one clear glass pane with low emissivity coating to provide the identical thermal properties. Both geometry designs of prismatic triple glazing has been integrated into facade module: frontal asymmetrical prism (left part of module) and reverse symmetrical rectangular prism (right part of module).

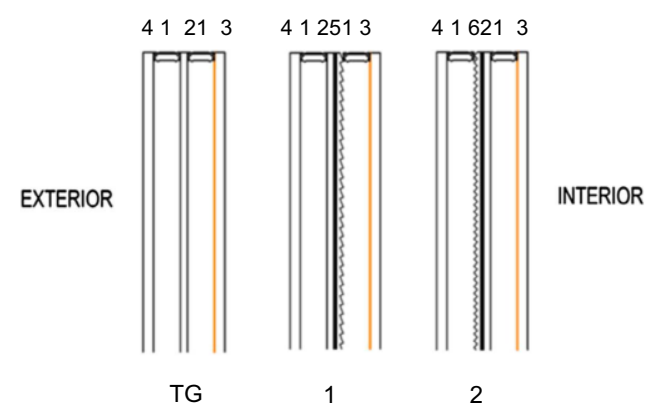

Fig. 5. Types of measured triple glazing (TG - conventional clear triple glazing; 1 - triple glazing with frontal asymmetrical prism; 2 - triple glazing with reverse symmetrical prism)

Table 1. Legend of layers presented in Fig. 5.

\begin{tabular}{|c|c|c|}
\hline Position & $\begin{array}{c}\text { Thickness } \\
{[\mathrm{mm}]}\end{array}$ & Layer \\
\hline 1 & 16 & Thermally insulating frame, air gap \\
\hline 2 & 3 & Clear pane \\
\hline 3 & 6 & $\begin{array}{c}\text { Glass pane with low emissivity } \\
\text { coating }\end{array}$ \\
\hline 4 & 6 & Clear pane \\
\hline 5 & 4 & Frontal asymmetrical glass prism \\
\hline 6 & 4 & Reverse symmetrical glass prism \\
\hline
\end{tabular}




\section{Experimental measurement}

For the purpose of the outdoor long-term monitoring of façade module the test cell has been designed and built (see in Fig. 6) on the experimental area of the UCEEB CTU in Bustehrad. Two different facade modules were installed on the south wall (azimuth $-15^{\circ}$ ) of the test cell. The modules differ in coating applied on the PVT glass absorber. Two glass prisms differ in geometry.

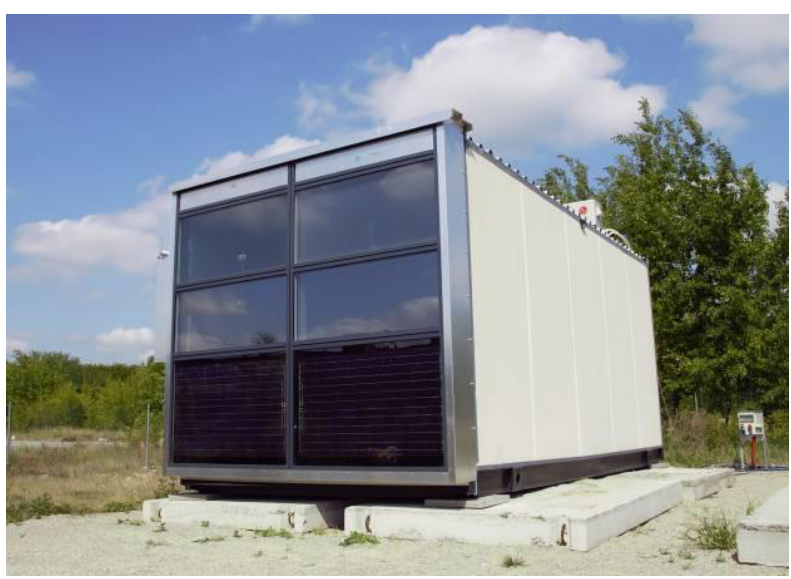

Fig. 6. Experimental test cell for energy-active façade module

Test cell is divided into two parts (rooms). First part is testing room with controlled indoor temperature (conditioned space), second part is technical room for necessary HVAC facilities, see energy system of the cell in Fig. 7. In the testing room there is an electrical heater and air chiller (water based) to maintain indoor temperature of the air. Both heating and cooling energy consumption is measured. In the technical room there are two storage tanks (solar tank and cooling water tank). Thermal energy from PVT collectors is stored in 1601 solar tank. This solar tank is every night discharged by cold water. Cooling water tank (200 1) is cooled down by adapted air-conditioning unit installed on the roof of the test cell. Cooling water from the tank is used for chiller placed in testing room and for night cooling of solar tank. Electrical energy from PVT collectors was used for charging of batteries first year of measurement. Batteries were regularly discharged every day by thermal resistance. Because of problems with control algorithm of discharging the PV part was connected directly to grid during the second year of monitoring period.

\subsection{Monitoring of PVT collectors}

Performance monitoring of both PVT collectors designs was carried out for three months during two year [11]. Results for selective PVT collector are presented in this paper. In Tab. 2. Measured energy gains for evaluated time periods are shown in Tab. 2. Incident solar irradiance was measured by pyranometer on the outer surface of the south wall. PVT collector thermal output was evaluated from measured flow rate and temperatures at the inlet and outlet of the PVT collector. Monthly average thermal efficiency varies from $35 \%$ to $50 \%$, monthly average electrical efficiency varies from 5.6 to $6.9 \%$. All efficiencies are related to gross area of the collector (packing factor is $60 \%$ ).

Table 2. Measured heat and electric gain of the PVT collector (gross area $1.56 \mathrm{~m}^{2}$ )

\begin{tabular}{|c|c|c|c|}
\hline \multirow{2}{*}{ Month } & $\begin{array}{c}\text { Incident solar } \\
\text { irradiation }\end{array}$ & $\begin{array}{c}\text { Measured heat } \\
\text { gain }\end{array}$ & $\begin{array}{c}\text { Measured } \\
\text { electrical } \\
\text { gain }\end{array}$ \\
\cline { 2 - 4 } & $\mathrm{kWh} /$ month & $\mathrm{kWh} /$ month & $\mathrm{kWh} /$ month \\
\hline $\begin{array}{c}\text { July } \\
2018\end{array}$ & 32.6 & 18.2 & 2.9 \\
\hline $\begin{array}{c}\text { July } \\
2019\end{array}$ & 109.2 & 94.6 & 9.9 \\
\hline $\begin{array}{c}\text { January } \\
2019\end{array}$ & 88.8 & 50.7 & 7.8 \\
\hline
\end{tabular}

Fig. 8 shows performance of PVT collector under standard function (heat removal from collector) and under stagnation (no heat removal). Thermal and electrical output is related to the gross area of the collector. At 5.00 am solar circulation pump turned on notwithstanding sun is not shinning. This phenomenon happened sometimes if the temperature in the storage is

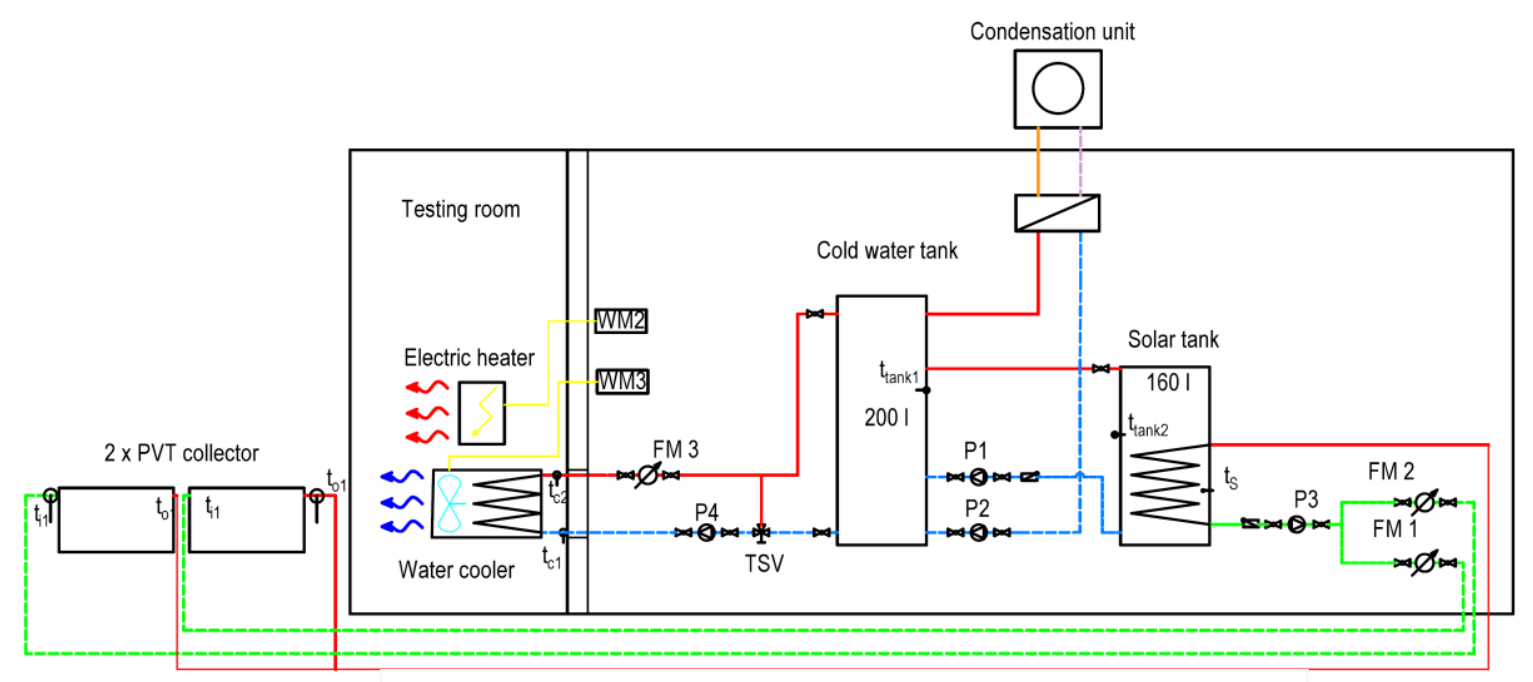

Fig. 7. Scheme of the energy system in the test cell (thermal part) 
lower than in the PVT collector due to night discharging of hot water storage. Thermal output during this period (sun is not shinning) was not taken into consideration in monthly sum. Until the afternoon PVT collector operates in hybrid mode (simultaneously heat and electric production). During afternoon the circulation pump was switched off to show that PV part can operate even during high temperatures. This measurement was done because glazed PVT collectors on the market can't operate in high temperatures than $85^{\circ} \mathrm{C}$. Stagnation temperature for PVT collector was measured $110^{\circ} \mathrm{C}$ during July 2019, boundary conditions during the measurement were: total tilted incident irradiance $600 \mathrm{~W} / \mathrm{m}^{2}$, ambient air temperature $28^{\circ} \mathrm{C}$, incidence angle of solar radiation was $61^{\circ}$.

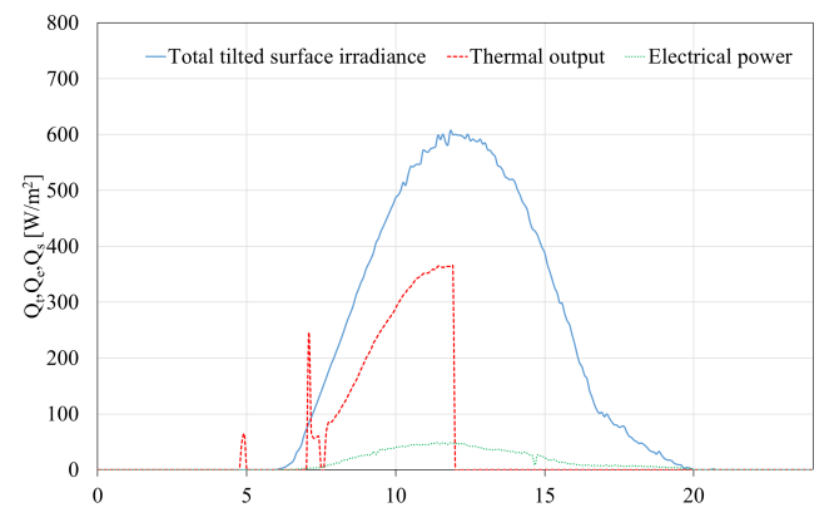

Fig. 8. Measurement of thermal and electrical performance of the glazed PVT collector (23. 7. 2019)

\subsection{Measurement of glass prism structures}

Four pyranometers were used for the evaluation of prismatic glazing function (see in Fig. 9). Solar irradiance incident on the facade was measured at the outer surface of the south wall of testing cell (position 3). Two pyranometers were installed behind triple glazings with two different glass prims (1 and 2) in top part of the facade module. Last pyranometer was installed behind conventional triple glazing in the middle of the façade module (TG).

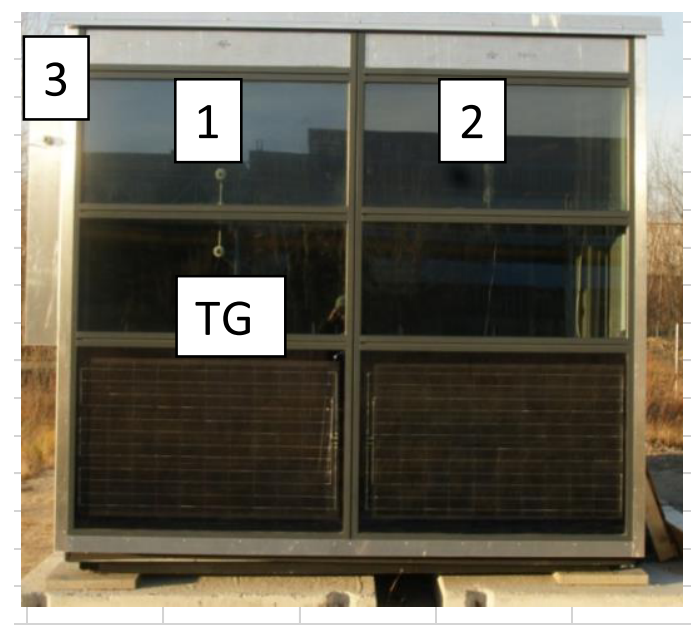

Fig. 9. Measurement of solar irradiance behind glass prisms (1 and 2), behind triple glazing (TG), and at the outer surface of the experimental test cell (4)

Tab. 3 and Tab. 4 show comparison of prismatic glazings benefits during winter and summer months within the monitoring period of two years. During winter, triple glazing with reverse symmetrical prism (2) exhibits higher transmitted solar irradiation to the testing room by 2 to $8 \%$ compared to conventional triple glazing. During summer, triple glazing with reverse symmetrical prism reflects from 39 to $46 \%$ more solar irradiance compared to conventional triple glazing. The functionality of prismatic structures has been proved. While winter heat gains are practically at comparable level, prisms can achieve significant reduction of cooling loads.

Table 3. Measured irradiation (monthly)

\begin{tabular}{|c|c|c|c|c|}
\hline & $\begin{array}{c}\text { Incident } \\
\text { irradiation } \\
\text { at the } \\
\text { south wall } \\
(3)\end{array}$ & $\begin{array}{c}\text { Behind } \\
\text { triple } \\
\text { glazing } \\
\text { Month }\end{array}$ & $\begin{array}{c}\text { Behind } \\
\text { frontal } \\
\text { asymmet } \\
\text { rical } \\
\text { prism (1) }\end{array}$ & $\begin{array}{c}\text { Behind } \\
\text { reverse } \\
\text { symmetric } \\
\text { al prism } \\
(2)\end{array}$ \\
\hline $\begin{array}{c}\text { January } \\
2018\end{array}$ & 26.8 & 10.3 & 10.2 & 11.1 \\
\hline $\begin{array}{c}\text { January } \\
2019\end{array}$ & 32.6 & 12.8 & 12.0 & 13.1 \\
\hline $\begin{array}{c}\text { July } \\
2018\end{array}$ & 109.2 & 37.3 & 29.2 & 20.3 \\
\hline $\begin{array}{c}\text { July } \\
2019\end{array}$ & 88.8 & 30.3 & 24.5 & 18.6 \\
\hline
\end{tabular}

Table 4. Evaluated difference prismatic glazing - conventional glazing

\begin{tabular}{|c|c|c|}
\hline Month & $\begin{array}{c}\text { Difference } \\
\text { between prism } \\
\text { 1and TG }\end{array}$ & $\begin{array}{c}\text { Difference } \\
\text { between prism } \\
\text { 2 and TG }\end{array}$ \\
\cline { 2 - 3 } & $\%$ & $\%$ \\
\hline January 2018 & -0.7 & 7.6 \\
\hline January 2019 & -6.0 & 2.2 \\
\hline July 2018 & -21.6 & -45.5 \\
\hline July 2019 & -19.0 & -38.8 \\
\hline
\end{tabular}

Fig. 10 shows progress of solar irradiance on every pyranometer. At the end of the day the irradiance is 
practically same at the each irradiance sensor in the test cell. That is caused by the orientation of the cell (azimuth $15^{\circ}$ to east) and due to this fact all pyranometers inside are already in a shadow.

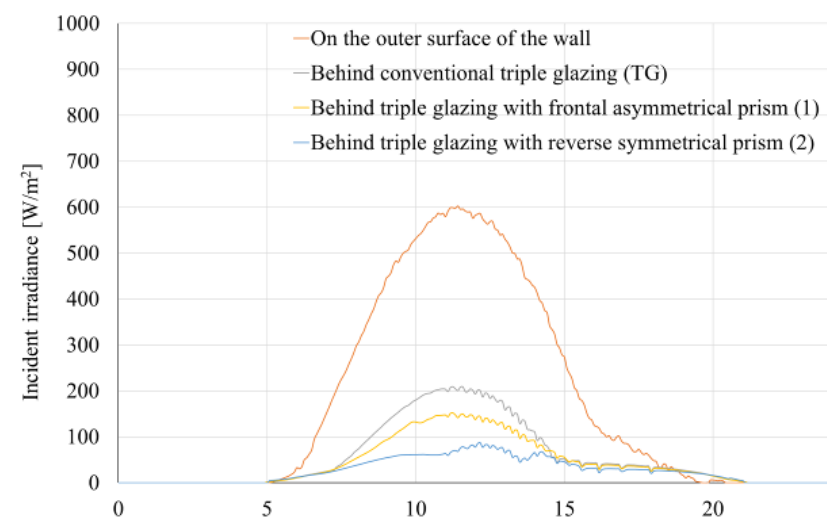

Fig. 10. Measurement of incident irradiance (3. 7. 2018)

\section{Conclusion}

New prototype of energy-active façade module was fabricated and monitored. Façade module is able produce energy and actively control solar heat gain during year. PVT collector integrated in the façade module can achieve solar yield during summer $58 \mathrm{kWh} / \mathrm{m}^{2}$.month in heat and $6.3 \mathrm{kWh} / \mathrm{m}^{2}$.month in electricity. Monthly average thermal efficiency varies from $35 \%$ to $50 \%$. Monthly average electrical efficiency varies from 5.6 to $6.9 \%$. Thermal performance of the glazed PVT collector is comparable to conventional solar thermal collectors on the market. Electrical production is lower compare to conventional PV panel because of additional cover glazing and high temperature operation. Nevertheless, goal application of developed PVT collector is preparation of domestic hot water and in this application PVT collector has advantage compare to solar thermal collectors in additional electricity production.

Triple glazing with the reverse symmetrical rectangular prism (apex angle $90^{\circ}$ ) has shown much better ability to reflects summer direct radiation, while allowing the winter solar heat gains. During summer this triple glazing with reverse symmetrical rectangular prism reflects from 39 to $46 \%$ more solar radiation than conventional triple glazing while winter heat gain is similar. Geometry of the prismatic structure is adapted for climatic conditions of Central Europe but it is not difficult to modify for different climatic conditions.

This work has been supported by the Ministry of Education, Youth and Sports within National Sustainability Programme I, project No. LO1605.

\section{References}

[1] W. Weiss, M. Spörk-Dür, Solar Heat Worldwide, IEA-Solar Heating and Cooling Programme. https://www.iea-shc.org/solar-heat-worldwide (2019)
[2] N. Aste, C. Del Pero, F. Leonforte, Water flat plate PV-thermal collectors: A review. Solar Energy 102, 98-115 (2014)

[3] H.A. Zondag, W.G.J. Van Helden, Stagnation temperature in PVT collectors. PV in Europe, Italy (2002)

[4] M. Lammle, C. Thoma, M. Hermann, A PVT Collector Concept with Variable Film Insulation and Low-emissivity Coating. In Energy Procedia (Vol. 91, 72-77 (2016)

[5] S. Harrison, C.A. Cruickshank, A review of strategies for the control of high temperature stagnation in solar collectors and systems, in: Energy Procedia (2012)

[6] T. Matuska, B. Sourek, V. Jirka \& N. Pokorny, Glazed PVT Collector with Polysiloxane Encapsulation of PV Cells: Performance and Economic Analysis. International Journal of Photoenergy (2015)

[7] V. Poulek, D.S. Strebkov, I.S. Persic \& M. Libra, Towards 50 years lifetime of PV panels laminated with silicone gel technology. Solar Energy, 86(10), 3103-3108 (2012)

[8] P. Dupeyrat, C. Menezo, M. Rommel, H.M. Henning, Efficient single glazed flat plate photovoltaic-thermal hybrid collector for domestic hot water system. Sol. Energy 85, (2012)

[9] J. Korecko, V. Jirka, B. Sourek, J. Cerveny, Module greenhouse with high efficiency of transformation of solar energy, utilizing active and passive glass optical rasters. Sol. Energy (2010)

[10] B. Sourek, V. Jirka, V. Shemelin \& T. Matuska, Experimental characterization of glazing with glass prisms. Solar Energy (2017)

[11]N. Pokorny, T. Matuska, B. Sourek, V. Jirka, Glazed PVT Collector Integrated Into Façade Module (2019) 